\title{
Detecting and Correcting Unmotivated Tense Shifts by EFL English-major Jordanian Undergraduates
}

\author{
Maisoun I. Abu-Joudeh \\ Department of English Language and Literature, Hashemite University, Zarqa, Jordan \\ Sahail M. Asassfeh \\ Department of Curriculum and Instruction, Hashemite University, Zarqa, Jordan \\ Yousef M. Al-Shaboul \\ Department of English Curriculum and Instruction, Hashemite University, Zarqa, Jordan \\ Halla A. Shureteh \\ Department of English Language and Literature, Hashemite University, Zarqa, Jordan
}

\begin{abstract}
A multi-dimensional process, writing demands that the writer coordinate several dimensions at a time, including grammar. Particularly in dealing with tenses, a good number of English-major EFL learners find it challenging to maintain a consistent tense during a writing task. They are usually unaware of the fact that tense shifts are necessary in some contexts but unnecessary in others. Students need to know that when they cast an essay in one tense, they need to remain consistent throughout. The researchers developed and administrated a grammatical error detection and correction test to 270 Jordanian English-major undergraduates with the aim of assessing their ability to detect and correct unmotivated tense shifts. Descriptive (percentage, mean, and standard deviation) and inferential statistics ( $t$ test and One-Way ANOVA) were used for data analysis using SPSS 20. The results revealed that the easiest tense type to identify was the simple past while the most difficult was the simple present. As for correction, the easiest was the simple past whereas the most difficult was the present perfect. The results also showed significant differences associated with students' GPA, academic level and perceived grammatical knowledge.
\end{abstract}

Index Terms-Arab EFL learners, error detection, error correction, tense shift

\section{INTRODUCTION}

Godfrey (1980) stresses the role of tense cohesion in making texts integrated pieces of discourse. He warns EFL learners that they must "retain and attend to the identity of tense continuities they establish if their production is to be judged acceptable"(p.94). The present study stems from this need to draw EFL instructors' attention to the importance of adopting a text-oriented approach to teaching tense to EFL learners. Any attempt at understanding utterances in isolation from the discoursal contexts in which they occur will be incomplete and piecemeal as learners are denied the opportunity of seeing the systematic relationships between form, meaning, and use (Nunan, 1998). Therefore, educators and pioneers in language teaching assert the importance of introducing authentic texts into the learning situation (Widdowson, 1979; Littlewood, 1981; Nunan, 1987, 1998; Peacock, 1997). Authentic materials help learners realize the communicative value of the grammatical structure being acquired.

Nunan (1998), a proponent of the communicative language teaching approach, asserts that learners need to be provided with opportunities to use their English for communicative purposes. He argues that unless learners are given the chance to explore grammar in context, they will not be able to see "how and why alternative forms exist to express different communicative meanings. For example, getting learners to read a set of sentences in the active voice, and then transform these into passives following a model, is a standard way of introducing the passive voice". Such practice, according to Nunan, would require that students are given" opportunities to explore when it is communicatively appropriate to use the passive rather than the active voice" (p.103).

Findings of empirical research (e.g., Rao, 2002; Tuan, 2011; Nunan, 1987) suggest that learners have a general preference to integrate both communicative and non-communicative activities in the EFL learning situation. Rao (2002), for instance, reported the views of 30 Chinese university students on the effectiveness of communicative and noncommunicative activities in EFL courses. Participants reported a preference for a combination of communicative (e.g., student-teacher interaction, student-student interaction, personal response to students' exercises and songs) and noncommunicative activities (e.g., workbook type drill and practice, audio-lingual drill, dictionary exercise, grammar rule explanation by the teacher, error correction and obedience to teacher's instruction) in their English classroom. All the 
subjects were aware of the fact that English learning could only be facilitated by a reconciliation of communicative and non-communicative activities.

Tuan (2011) examined the effectiveness of task-based learning as a means of accommodating learners' needs and promoting communication. The findings of the study revealed that the task of negotiation positively impacted students' communicative competence as it "generated motivation and involvement, promoted their learning initiative, enhanced their sense of progress, and facilitated group cohesion"(p.24). This in turn, proved the productivity and workability of the communicative approach. Students' responses to the tasks also proved their acceptance of the approach. Therefore, one of the underlying assumptions undertaken by the researchers of this paper is that Arab EFL learners should receive a considerable amount of well-balanced meaning-oriented and form-focused instruction through authentic communication before they can use the language in real life. This is in line with a recent general shift toward using techniques where students are more actively involved. In line with this understanding, the researchers in this study presented the participants with an authentic text instead of discrete sentences to investigate their understanding of tense relations and eventually detecting unmotivated tense shifts. The study proposes that a combination of meaning-oriented and form-focused instruction must be implemented towards communicatively competent language learners.

\section{LITERATURE REVIEW}

Language learning is fundamentally "learning how to operate the verbal forms of that language" (Palmer, 1965, p.5). It is thus plausible to claim that failure to master the verb forms of the target language makes errors inevitable in the process of learning a foreign language (Dulay \& Burt, 1974; Liu, 2012). Much of the studies conducted on Arab EFL learners' writings reveal that English temporal system is one of the difficult grammatical areas for EFL learners to master (Kambal, 1980; Abdul Haq, 1982; Mukattash, 1983; Mattar, 2001; Farrokh, 2011; Al-Hazaymeh, 1994; AlKhasawneh, 2010; Mourtaga, 2006, 2010). Kambal (1980), for instance, analyzed the writings of first year Sudanese university students with the aim of identifying the syntactic errors made by these students in the verb phrase. He found that three types of errors featured in the students' use of the verb phrase: verb formation, tense, and subject-verb agreement. Errors in tense included tense sequence, tense substitution, tense marker, deletion, and confusion of perfect tenses. Mukattash's (1983) wide-scale study reported similar problems; students make serious syntactic errors when trying to express themselves communicatively, which is attributed mainly to students' lack of motivation and ineffective teaching methodology.

Mattar's (2001) investigation of Arab EFL learners' writings revealed that students systematically replaced the present perfect tense in English with the simple past tense. Students' attempt to avoid the appropriate tense in question was attributed to the fact that students were unable to establish proper form-meaning/tense associations. Farrokh (2011) analyzed errors made by 50 Iranian EFL learners. Among most common mistakes made by students was inappropriate use of tenses. Her argument was that students were unable to render the tense in question because of lack of structural correspondence between the mother tongue and the target language.

This line of inquiry is supported by the findings of studies based on computer learner corpora, electronic collections of spoken and written texts produced by foreign/second language learners. For example, Granger (1999) reported inappropriate tense shifts by EFL French learners. He argued that students were taught tenses at the sentence level and thus were not aware of discoursal context in their use of tenses in English. He concluded that tenses should be taught at discourse level. Liu (2012) conducted an error analysis of the learner's writing competence based on Chinese Learner English Corpus (CLEC). The corpus collected more than 1000,000 words from the written production of Chinese learners at different proficiency levels. It was found that even advanced-level learners had repeated difficulties using tenses. Simple present tense was the most frequently misused tense, followed by misuse of simple past tense. These were followed by misuses of past perfect tense and present perfect tense. Present progressive tense, present perfect progressive tense, past progressive tense, future tense and past future tense were misused less frequently in the corpus. No misuses of future perfect progressive tense, past future progressive tense and past future perfect progressive tense were found. Granger attributed errors in tense use to mother tongue influence, target language interference and cognitive factors.

The findings of these studies coincide with one of the basic principles of the communicative language teaching approach. Any attempt by EFL learners to produce efficient English in real life situations is hindered by their inability to use language for communication. Instructors need to provide learners with practice that focuses on both grammatical accuracy and discoursal context in an attempt to arrive at an integrated piece of writing. Moreover, most previous studies adopt a production-based assessment to identify grammatical errors made by students. Due to the fact that EFL learners sometimes tend to use avoidance as a strategy to steer around from those aspects of the grammar of English over which they have no or limited mastery, this entails a real risk. Therefore, the present study asks students to judge whether a tense verb is appropriately used as a way of assessing their knowledge of L2. The benefit of asking students to detect and correct errors is that it gives the researcher a chance to highlight those aspects of the target language students intentionally steer around. Based on the issues raised in the review of relevant literature, this study attempted to answer the following questions:

RQ1: To what extent are English-major Jordanian undergraduates capable of detecting and correcting unmotivated tense shifts? 
RQ2: Is there any significant relationship $(\alpha=.05)$ between students' ability to detect and correct unmotivated tense shifts and their GPA, academic level and perceived grammatical competence?

RQ3: Is there any significant correlation $(\alpha=.05)$ between students' ability to detect and correct errors?

\section{METHOD}

\section{A. Participants}

The participants of the study were 270 English-major undergraduate students enrolled at a public university where they are required to choose their majors upon entering college. Since most students begin their first year by enrolling in general education courses that are approximations of the necessary prior general academic knowledge and are rarely enrolled in courses that contribute to their advancement in language per se, they were intentionally excluded from this study. The students in this study were either in their second $(n=112)$, third $(n=81)$ or fourth academic year $(n=77)$ at the time when the study was conducted. Since Grade Point Average (GPA) is a commonly used indicator of academic performance, the students were categorized into three groups according to GPA (low=2.5-3.; intermediate=3.1-3.50, and high=3.51-4). Participants were asked to answer a two- part instrument. The first part elicited general information (e.g., gender, GPA, and academic year) whereas the second part elicited information about participants' performance associated with their ability to detect and correct errors pertinent to tense shift.

\section{B. Instrument}

To assess students' ability to detect and correct errors related to tense shifting, a test was designed for this purpose. The test included 24 unmotivated tense shifts distributed over four paragraphs that included a total of 336 words. It was designed to include multiple occurrences of four English tenses, namely simple past, simple present, past perfect and present perfect. To ensure the validity of the instrument, the test was given to five university professors. They were requested to indicate: (a) their belief about the appropriateness of the text to students' level; (b) whether there is an ambiguity in the target verb tense in each occurrence; and (c) the appropriateness of the text length for the study participants.

\section{Procedures and Analyses}

270 copies of the instrument were produced and then administrated to students in the presence of one of the researchers. The test was conducted during regular class time. Having been informed of the purpose of the study and the importance of their participation, students were asked to sign the informed consent form. The test came with a twocolumn table that required students to list the errors detected in the first column and to correct the error in the second column.

\section{Statistical Analysis}

The data for this study was analyzed using SPSS version 20. Both descriptive (mainly the mean and standard deviation) and inferential statistics ( $t$ test and One-Way ANOVA) were used.

\section{RESUlts}

This paper has two foci: (a) to depict students' ability to detect and correct errors pertinent to unmotivated tense shift and (b) to investigate the impact of demographic variables (academic year, GPA and students' perceived grammatical competence). Table 1 sheds light on students' performance pertinent to error detection and error correction on the overall test.

TABLE 1.

STUDENTS' RESULTS ON THE OVERALL TEST IN TERMS OF ERROR DETECTION AND ERROR CORRECTION

\begin{tabular}{llllll}
\hline & $\mathrm{N}$ & Minimum & Maximum & Mean & SD \\
\hline Error Detection & 270 & 2.00 & 22.00 & 9.41 & 4.27 \\
\hline Appropriate Correction & 268 & .00 & 21.00 & 4.98 & 3.59 \\
\hline
\end{tabular}

The results indicate that the mean response on the overall error detection test was as low as 9.41/ 24.00. Astonishingly, the mean response on students' correct responses was much lower $(M=4.98 / 24.00)$. Since the test included 24 errors, and the participants were 270, the maximum possible score for the entire group of participants was 6480. Among this total, the participants managed to detect 2542 errors. This means that the percentage of detected errors was $39 \%$. Since the number of errors on the different tenses was not equal on the test, the mean values are used to show the discrepancy in students' performance on these tenses. Ordered from easy to difficult to detect, the shifted tenses came as follows: (a) simple past $(M=.56, \mathrm{SD}=.30)$; (b) past perfect $(M=.49, \mathrm{SD}=.32)$; (c) present perfect $(M=.40, \mathrm{SD}=.25)$; and $(\mathrm{d})$ simple present $(M=.19, \mathrm{SD}=.19)$. 
TABLE 2.

DESCRIPTIVE STATISTICS FOR STUDENTS' PERFORMANCE ON ERROR DETECTION BY TENSE TYPE

\begin{tabular}{lll}
\hline & Mean & SD \\
\hline Simple Past & .56 & .30 \\
Past Perfect & .49 & .32 \\
Present Perfect & .40 & .25 \\
Simple Present & .19 & .19 \\
\hline
\end{tabular}

The results of students' performance on error correction by tense type (Table 3 ) indicate that the easiest to correct was the simple past, followed by the simple present and the past perfect. The most problematic to correct was the present perfect. The number of errors appropriately corrected was 1326. Divided by the total number of errors on the test (6480), it becomes clear that they managed to appropriately correct almost $20 \%$ of the entire pool of errors on the test. It also becomes clear that compared to the number of detected errors, the students managed to correct almost $52 \%$.

TABLE 3.

RESULTS FOR STUDENTS' PERFORMANCE ON ERROR CORRECTION BY TENSE TYPE

\begin{tabular}{lll}
\hline & Mean & Std. Deviation \\
\hline Simple Past & 2.51 & 1.35 \\
Simple Present & 1.69 & 1.18 \\
Past Perfect & 1.03 & 1.33 \\
Present Perfect & .81 & 1.12 \\
\hline
\end{tabular}

It is also beneficial to see the frequency of detection and correction by individual errors.

TABLE 4.

\begin{tabular}{|c|c|c|c|c|c|c|c|c|c|}
\hline $\begin{array}{l}\text { Error } \\
\text { No. }\end{array}$ & Error Type & $\begin{array}{l}\text { Dete } \\
\text { Dete } \\
\text { No. }\end{array}$ & $\%$ & $\begin{array}{l}\text { Und } \\
\text { No. }\end{array}$ & $\%$ & $\begin{array}{l}\text { Corr } \\
\text { Corr } \\
\text { No }\end{array}$ & $\%$ & $\begin{array}{l}\text { Inco } \\
\text { No }\end{array}$ & $\%$ \\
\hline 1 & Simple Past & 192 & 71.1 & 78 & 28.9 & 186 & 68.9 & 2 & .7 \\
\hline 2 & Present Perfect & 149 & 55.2 & 121 & 44.8 & 45 & 16.7 & 94 & 34.8 \\
\hline 3 & Simple Present & 68 & 25.2 & 201 & 74.4 & 64 & 23.7 & 2 & .7 \\
\hline 4 & Simple Present & 26 & 9.6 & 244 & 90.4 & 22 & 8.1 & 4 & 1.5 \\
\hline 5 & Simple Present & 22 & 8.1 & 248 & 91.9 & 21 & 7.8 & 1 & .4 \\
\hline 6 & Present Perfect & 94 & 34.8 & 176 & 65.2 & 25 & 9.3 & 60 & 22.2 \\
\hline 7 & Simple Present & 67 & 24.8 & 203 & 75.2 & 53 & 19.6 & 7 & 2.6 \\
\hline 8 & Present Perfect & 90 & 33.3 & 180 & 66.7 & 24 & 8.9 & 53 & 19.6 \\
\hline 9 & Simple Present & 41 & 15.2 & 229 & 84.8 & 35 & 13.0 & 4 & 1.5 \\
\hline 10 & Simple Present & 13 & 4.8 & 257 & 95.2 & 10 & 3.7 & 2 & .7 \\
\hline 11 & Simple Present & 116 & 43.0 & 154 & 57.0 & 79 & 29.3 & 19 & 7.0 \\
\hline 12 & Simple Past & 143 & 53.0 & 126 & 46.7 & 99 & 36.7 & 40 & 14.8 \\
\hline 13 & Present Perfect & 116 & 43.0 & 154 & 57.0 & 19 & 7.0 & 86 & 31.9 \\
\hline 14 & Simple Past & 148 & 54.8 & 122 & 45.2 & 117 & 43.3 & 29 & 10.7 \\
\hline 15 & Past Perfect & 105 & 38.9 & 165 & 61.1 & 57 & 21.1 & 46 & 17.0 \\
\hline 16 & Present Perfect & 105 & 38.9 & 165 & 61.1 & 18 & 6.7 & 75 & 27.8 \\
\hline 17 & Present Perfect & 102 & 37.8 & 168 & 62.2 & 49 & 18.1 & 77 & 17.4 \\
\hline 18 & Past Perfect & 172 & 63.7 & 98 & 36.3 & 51 & 18.9 & 113 & 41.9 \\
\hline 19 & Past Perfect & 111 & 41.1 & 159 & 58.9 & 17 & 6.3 & 91 & 33.7 \\
\hline 20 & Past Perfect & 128 & 47.4 & 142 & 52.6 & 35 & 13.0 & 89 & 33.0 \\
\hline 21 & Past Perfect & 125 & 46.3 & 143 & 53.0 & 38 & 14.1 & 84 & 31.1 \\
\hline 22 & Past Perfect & 142 & 52.6 & 127 & 47.0 & 40 & 14.8 & 100 & 37.0 \\
\hline 23 & Simple Past & 80 & 29.6 & 189 & 70.0 & 53 & 19.6 & 26 & 9.6 \\
\hline 24 & Simple Past & 187 & 69.8 & 81 & 30.0 & 174 & 64.4 & 6 & 2.2 \\
\hline
\end{tabular}

The Impact of Demographics

\section{A. Academic Level}

To see whether students' responses on error detection and error correction differed statistically according to their academic year, On-Way ANOVA was used. The results (Table 5) indicate significant differences on both: error detection and error correction.

TABLE 5.

ANOVA RESULTS FOR PERFORMANCE ON ERROR DETECTION AND ERROR CORRECTION BY THE ACADEMIC YEAR

\begin{tabular}{lllllll}
\hline & & Sum of Squares & Df & Mean Square & F & Sig. \\
\hline \multirow{2}{*}{ Error } & Between Groups & 569.52 & 3 & 189.84 & 11.65 & .000 \\
Detection & Within Groups & 4336.02 & 266 & 16.30 & & \\
& Total & 4905.541 & 269 & & 7.98 & .000 \\
Error & Between Groups & 286.52 & 3 & 95.51 & 11.97 & \\
Correction & Within Groups & 3159.35 & 264 & & \\
& Total & 3445.87 & 267 & & & \\
\hline
\end{tabular}


Post-hoc analyses, using Scheffe, indicated that pertinent to error detection, fourth-year students $(M=11.32, \mathrm{SD}=4.25)$ outperformed first-year students $(M=8.00, \mathrm{SD}=4.03)$. Third-year $(M=9.79, \mathrm{SD}=4.41)$ and fourth-year students also outperformed second-year students $(M=7.81, \mathrm{SD}=3.45)$. As for error correction, post-hoc comparisons indicated that fourth-year students $(M=6.42, \mathrm{SD}=4.27)$ outperformed first $(M=3.92, \mathrm{SD}=3.05)$ and second-year students $(M=3.91$, $\mathrm{SD}=2.31)$, but not third-year students $(M=5.08, \mathrm{SD}=3.74)$. These results indicate that despite the gap in students' ability in error detection, the differences among first, second, and third-year students are less clear when it comes to error correction. This is evident since the difference in performance on error correction was limited to the performance of fourth-year students compared to each of the other three.

\section{B. Academic Performance}

ANOVA results indicated statistically significant differences between the three groups $(\mathrm{P}<.01)$. This was the case for both detection and correction.

TABLE 6.

ANOVA RESULTS FOR ERROR DETECTION AND CORRECTION BY GPA

\begin{tabular}{|c|c|c|c|c|c|c|}
\hline & & Sum of Squares & Df & Mean Square & $\mathrm{F}$ & Sig. \\
\hline \multirow{3}{*}{$\begin{array}{l}\text { Error } \\
\text { Detection }\end{array}$} & Between Groups & 426.87 & 2 & 213.43 & \multirow[t]{3}{*}{12.72} & \multirow[t]{3}{*}{.000} \\
\hline & Within Groups & 4478.67 & 267 & 16.77 & & \\
\hline & Total & 4905.54 & 269 & & & \\
\hline \multirow{3}{*}{$\begin{array}{l}\text { Error } \\
\text { Correction }\end{array}$} & Between Groups & 439.44 & 2 & 219.72 & \multirow[t]{3}{*}{19.37} & \multirow[t]{3}{*}{.000} \\
\hline & Within Groups & 3006.43 & 265 & 11.35 & & \\
\hline & Total & 3445.87 & 267 & & & \\
\hline
\end{tabular}

Post-hoc comparisons, using Scheffe, revealed that in terms of detection, high-achievers $(M=12.35, \mathrm{SD}=5.16)$ outperformed both low $(M=6.95, \mathrm{SD}=2.82)$ and intermediate $(M=9.18, \mathrm{SD}=4.00)$ achievers. However, the mean difference between low and intermediate-achievers was not significant. As for correction, there were statistically significant differences between all pairs of groups. The mean responses followed a pattern; the higher the GPA, the higher the ability in error correction (Means of 2.53, 4.72, and 8.00 for the low, intermediate, and high-achievement groups respectively).

\section{Perceived Grammatical Competence}

Classified according to their reported grammatical competence, the students were classified into four groups: poor, good, very good, and excellent. Possible significant differences among these groups according to their perceived grammatical competence were carried out using One-Way ANOVA. The results (Table 7) indicated there were significant differences.

TABLE 7.

STUDENTS' ABILITY IN ERROR DETECTION AND ERROR CORRECTION BY PERCEIVED GRAMMATICAL COMPETENCE

\begin{tabular}{lllllll}
\hline & & Sum of Squares & Df & Mean Square & F & Sig. \\
\hline \multirow{2}{*}{ Error } & Between Groups & 321.70 & 3 & 107.23 & 6.22 & .000 \\
\multirow{2}{*}{ Detection } & Within Groups & 4583.84 & 266 & 17.23 & & \\
& Total & 4905.54 & 269 & & & \\
\hline \multirow{2}{*}{ Error } & Between Groups & 314.90 & 3 & 104.97 & .000 & \\
& Within Groups & 3130.97 & 264 & 11.86 & \\
& Total & 3445.87 & 267 & & \\
\hline
\end{tabular}

Post-hoc comparisons revealed that pertinent to error detection, both excellent $(M=12.45, \mathrm{SD}=2.54)$ and very good $(M=10.50, \mathrm{SD}=4.53)$ students outperformed $\operatorname{good}(M=8.67, \mathrm{SD}=4.08)$ students $)$. As for correction, more groups were involved in the significant difference. Excellent $(M=7.64, \mathrm{SD}=2.98)$ and very good $(M=6.07, \mathrm{SD}=4.07)$ students outperformed each of the good $(M=4.31, \mathrm{SD}=3.12)$ and poor $(M=2.75, \mathrm{SD}=2.18)$ groups.

\section{DISCUSSION}

The present study aimed at assessing Jordanian EFL learners' ability to detect and correct unmotivated tense shifts. Students were able to detect a total of 2542 out of 6480 . Compared to the total number of errors on the test for all participants (6480), students managed to detect a ratio as low as 39\%, which means they detected almost one third of the entire set of errors they were presented with. Based on the mean values, the easiest error tense type to detect was simple past, followed by past perfect whereas the most difficult was simple present, followed by present perfect. The results pertinent to error correction indicated that the percentage of the errors properly corrected (1326) to those detected (2542) was almost 52\%. Based on the mean values, the easiest error tense type to correct was the simple past, followed by simple present and past perfect, whereas the most difficult was present perfect. These results go in line with the researchers' pre assumptions that mastering English tense system is both challenging and problematic. They also make it clear that when certain forms cluster together, it becomes difficult for learners to choose the most appropriate verb tense. One possible reason behind students' difficulty in detecting and correcting errors pertinent to tense is lack of focus on the form-meaning relationships at the text level. In other words, the treatment of the form-meaning 
combinations at the level of the sentence is insufficient. Dealing with these associations at the text level adds to students' understanding of the value of these meanings and the contexts in which they are used. (Larsen-Freeman et al 2002). Therefore, the best approach to grammar teaching must be viewed as one that focuses on an integration of form, meaning and use. The findings of the study go in line with the conclusions of Mattar (2001) that the tendency to miss the appropriate tense in question is due the lack of focus on the tense-aspect associations in teaching grammar on the part of EFL instructors.

The second question addressed by the present study was whether there is a relationship between students' performance and their GPA, academic level and perceived grammatical knowledge. The results indicated that there is a significant relationship between students' ability to detect and correct tense shift errors and their GPA. The results pertinent to error detection showed that a border line can be drawn between high achievers and both intermediate and low achievers. As for correction, all pairs of groups demonstrated statistically significant differences. Students with high GPA were found to be more inclined to do well than those with lower GPA. This suggests that students may register very poor performance when they show week commitment to their academics. Additionally, academic level was found to impact students' performance. The findings showed that fourth year students did better than first year students. Together with third year students, fourth year students outperformed second year students in error detection. In terms of error correction, fourth year students outperformed all levels but third year students. The difference in performance between the first, second, and third year students was not significant. This suggests that length of language study is positively related to good academic performance.

The results also revealed that students' ability to detect and correct error is inseparable from their perceived grammatical competence. Excellent and very good students outperformed good students with regard to error detection. In terms of correction, excellent and very good students outperformed good and poor students. That is, the significant difference in both error detection and correction sets excellent and very good students apart from good and low students. This finding is plausible since advanced students are assumed to be more able to identify errors as they possess more advanced grammatical knowledge.

It is of equal importance to mention that there are cases in which students detected errors but never attempted to correct them. The worst-case scenario is that students' detection of tense shifts was done by chance and not by full awareness. The best-case scenario is that students were fully aware of the errors but never attempted to correct them because they thought that error detection revealed more about their grammatical competence than would error correction. Choosing either scenario would entail risk in absence of evidence.

\section{CONCLUSION}

Appropriate use of tenses is the most frequently reported linguistic problem faced by Arabic learners of English. The present study aimed at assessing Jordanian EFL learners' ability to detect and correct unmotivated tense shifts. The results of the study revealed that the most difficult errors to detect were pertinent to simple present and present perfect. Strangely enough, the results also demonstrated that students were able to correct errors pertinent to simple present. Though it was not easy to detect for most students, it was the easiest to correct, compared to past perfect and present perfect. One important implication of the present study is that EFL instructors should be aware of the fact that making mistakes on the part of EFL learners is inevitable. However, their role becomes more crucial in raising students' awareness to those aspects of the target language in which they face problems. They need to provide their students with extensive practice in authentic contexts to help them overcome their difficulties. The results of this study are expected to help teachers as well as materials designers in recognizing the most challenging and problematic areas of English grammar faced by students.

\section{REFERENCES}

[1] Abdul Haq, F. (1982). An analysis of syntactic errors in the composition of Jordanian secondary students. M.A. thesis, Yarmouk University.

[2] Al-Hazaymeh, Y. (1994). An analysis of the errors made by Jordanian secondary students in learning English verb tenses. M.A. thesis, Yarmouk University.

[3] Al-Khasawneh, F. (2010)._Writing for academic purposes: Problems faced by Arab postgraduate students of the college of Business, UUM. ESP World 9.2 (28). http://www.esp-world.info. (accessed 13/3/2014).

[4] Dulay, H., \& M. Burt. (1974). You can't learn without goofing. In J. C. Richards (ed.), Error analysis: Perspectives on second language acquisition. London: Longman, 95-124.

[5] Farrokh, P. (2011). Analyzing of EFL learners' linguistic errors: Evidence from Iranian translation trainees. Theory and Practice in Language Studies 1.6, 676-680.

[6] Granger, S. (1999). Use of tenses by advanced EFL learners: evidence from an error-tagged computer corpus. In H. Hasselgard \& S. Oksefjell (eds.) Out of corpora-Studies in honor of Stig Johansson. Rodopi: Amsterdam \& Atlanta, 191-202.

[7] Godfrey D. L. (1980). A discourse analysis of tense in adult ESL monologues. In D. Larsen-Freeman (ed.), Discourse analysis in second language research. Rowley: Newbury House, 92-110.

[8] Kambal, M. (1980). An analysis of Khartoum University students' composition errors with implications for remedial English in the context of Arabicization. Ph.D.Dissertation, University of Texas.

[9] Littlewood, W. (1981). Communicative language teaching: An introduction. Cambridge: Cambridge University Press. 
[10] Larsen-Freeman, D., T. Kuehn, \& M. Haccius. (2002). Helping students make appropriate verb tense-aspect choices. TESOL Journal 11. 4, 3-9.

[11] Liu, Juan. (2012). CLEC-based study of tense errors in Chinese EFL learners' writings. World Journal of English Language 2.4, 11-23.

[12] Mattar, H. (2001). Is avoidance a reflection of mother tongue interference? The case of the present perfect tense. International Journal of Arabic-English Studies 2, 2, 141-155.

[13] Mourtaga, K. R. (2006). Some reading problems of Arab EFL students. Journal Al-Aqsa University 10.2, 75-91.

[14] Mourtaga, K.R. (2010) Poor writing in English: A case of the Palestinian EFL learners in the Gaza Strip. Gaza: Alquds Open University.

[15] Mukattash, L. (1983) The problem of difficulty in foreign language learning. In E. Dahiyat and M. Ibrahim (eds.). Papers from the first conference on the problems of teaching English language and literature at Arab universities. Amman, University of Jordan.

[16] Nunan, D. (1987). Communicative language teaching: making it work. ELT Journal 41.2, 136-145.

[17] Nunan, D. (1998). Teaching grammar in context. ELT Journal 52.2, 101-109.

[18] Palmer, F. R. (1965). A Linguistic study of the English verb. London: Longman.

[19] Widdowson, H. (1979). Teaching language as communication. Oxford: Oxford University Press.

[20] Peacock, M. (1997). The effect of authentic materials on the motivation of EFL learners. ELT Journal 51.2, 144-156

[21] Rao, Z. (2002). Chinese university students' perceptions of communicative and non-communicative activities in EFL classroom. System 30, 85-105.

[22] Tuan, L.T. (2011). Negotiating tasks in EFL classrooms. Journal of Language Teaching and Research 2.1, 13-25.

Maisoun I. Abu-Joudeh is an Assistant Professor in the Department of English Language and Literature at the Hashemite University. She has published in many international journals. Her current research interests include syntax, phonology, language teaching and translation.

Sahail M. Asassfeh holds a B. A in English Language and Literature, a High Diploma in Education, a Master's degree, and a PhD in applied linguistics. He taught English at public and private basic and secondary schools for several years. He also worked as a preservice-training supervisor of English. Dr. Asassfeh currently teaches in the Departments of English Language and Literature \& Curriculum and Instruction at the Hashemite University, Jordan. He has many publications in several international journals.

Yousef M. Al-Shaboul holds his PhD in Reading from University of North Texas, Denton, Texas in 2004. Upon receiving his Diploma, he taught at Midwestern State University, Wichita Fall, for one year as a Visiting Professor. Now, he is an associate professor at College of Education (Department of Curriculum \& Instruction) and College of Art (Department of English) at The Hashemite University--Jordan. His areas of interest are reading, language arts, assessment, EFL, and family literacy. Dr. Al-Shaboul has many publications in different areas of interests in many international journals.

Halla A. Shureteh, Assistant Professor of Comparative Literature and Translation Studies, has a Ph. D. from State University of New York at Binghamton (USA), 2005. Currently she works in the Department of English language and Literature at the Hashemite University, Jordan. Her research interests include primarily contemporary Arabic translation, postcolonial studies, the philosophy of translation, literary translation, translator/interpreter training, translation quality assessment, and contemporary American women writers. She has published articles on translation studies and comparative literature with emphasis on contemporary literary and translation theories. 